\title{
The disparities in health insurance ownership of hospital-based birth deliveries in eastern Indonesia
}

\author{
Agung Dwi Laksono ${ }^{1,2^{*}}$, Ratna Dwi Wulandari ${ }^{3}$, Zuardin Zuardin ${ }^{2,4}$ and Nopianto Nopianto ${ }^{2,5}$
}

\begin{abstract}
Background: Development in Eastern Indonesia tends to be left behind compared to other Indonesian regions, including development in the health sector. The study aimed at analyzing the health insurance ownership disparities in hospital delivery in Eastern Indonesia.

Methods: The study draws on secondary data from the 2017 Indonesia Demographic and Health Survey. The study population was women aged 15-49 years who had given birth in the last five years in Eastern Indonesia. The study analyzes a weighted sample size of 2299 respondents. The study employed hospital-based birth delivery as a dependent variable. Apart from health insurance ownership, other variables analyzed as independent variables are province, residence type, age group, marital status, education level, employment status, parity, and wealth status. The final stage analysis used binary logistic regression.

Results: The results showed that insured women were 1.426 times more likely than uninsured women to undergo hospital delivery (AOR 1.426; 95\% Cl 1.426-1.427). This analysis indicates that having health insurance is a protective factor for women in Eastern Indonesia for hospital delivery. There is still a disparity between insured and uninsured women in hospital-based birth deliveries in eastern Indonesia. Insured women are nearly one and a half times more likely than uninsured women to give birth in a hospital.
\end{abstract}

Conclusion: The study concludes that there are health insurance ownership disparities for hospital delivery in eastern Indonesia. Insured women have a better chance than uninsured women for hospital delivery.

Keywords: Health insurance, Maternity care, Maternal health, Woman health, Eastern Indonesia

\section{Introduction}

World Health Organization (WHO) notes that, in the case of births and delivery or within 42 days of pregnancy termination, mother mortality (MMR) is the annual number of female deaths due to all factors related to or caused by or for the period and site of the

\footnotetext{
* Correspondence: ratna-d-w@fkm.unair.ac.id

'National Institute of Health Research and Development, the Ministry of Health of the Republic of Indonesia, Jakarta, Indonesia

${ }^{2}$ Persakmi Institute, Surabaya, Indonesia

Full list of author information is available at the end of the article
}

pregnancy. Except for causes of accident or event [1]. One of the Sustainable Development Goals (SDGs) goals is to reduce the MMR globally to less than 70 per 100,000 live births by 2030 [2].

Referring to the Ministry of Health of the Republic of Indonesia's annual report in 2019, maternal deaths were 4221 cases. This number has decreased slightly compared to 2018, which amounted to 4226 cases. It consists of maternal mortality caused by bleeding in 1280 instances, hypertension in pregnancy in 1066 cases, infection in 207 patients, circulatory system disorders in 200 
cases, metabolic disorders in 157 points, and other causes 1311 cases [3].

Every day 38 mothers in Indonesia die from diseases/ complications related to pregnancy and complications [4]. We could have been preventing most of these deaths. It means that we could avoid and saved if the MMR was high. Indonesia's MMR trend has decreased from 2000 to 2017 (272 per live birth to 177 per 100,000 live births) but has not yet reached the SDGs target globally [4]. Compared with the MMR trend from 2000 to 2017 in the Southeast Asia region, Indonesia has the highest Maternal Mortality Rate. The lowest is in Singapore (8 per 100,000 live births). Moreover, at the global level, there are at least 830 maternal deaths in the world every day [4].

Previous studies found that $14.3 \%$ of maternal mortality was due to abortion bleeding and uterine rupture, followed by eclampsia in $12.5 \%[5,6]$. On the other hand, other causes of maternal death were infection (sepsis) by $10.7 \%$, then abortion and embolism by $7.9 \%$. The rest are of unknown reasons [7]. We handled incorrect and on-time maternal deaths caused by obstetric complications. About $15 \%$ of pregnancies/deliveries have difficulties; they have required quality service readiness at all times. Quick access to quality emergency services is needed, as some complications require emergency care within hours, especially in hospitals, to get complete delivery services $[5,6]$. Delay in assisting can cause maternal death. A previous study found at least three delays to cause maternal death: late in making decisions, late arrival at the referral place, and late getting help at the referral place [8].

Several lessons inform caused delays in delivery assistance in eastern Indonesia by access to health facilities and costs incurred during childbirth $[9,10]$. Moreover, in the territory of Indonesia, the distribution of hospitals in each region is imbalanced. The disparity in hospital availability also affects the accessibility to delivery at the hospital $[11,12]$. Besides, the cost is quite expensive to influence mothers to take advantage of hospital services, especially in Eastern Indonesia $[10,13]$.

One of the Indonesian government's policies is to achieve universal health coverage to overcome these conditions. The government does it through the $\mathrm{Na}$ tional Health Insurance (NHI). NHI is a form of financial guarantee when the mother wants to give birth in the hospital. The NHI contributes by making it easier for them to access finance, reducing their labor burden [14-16]. Several studies have reported that the NHI can increase women's access to childbirth in the hospital [15, $17,18]$. This situation is the basis for knowing the importance of differences in health insurance ownership among women who give birth in eastern Indonesia hospitals. This study's results are significant for policymakers to encourage policies that focus on increasing deliveries to hospitals. This study aimed to analyze health insurance ownership disparities in hospital delivery in Eastern Indonesia based on the background description.

\section{Materials and methods}

\section{Data source}

The author conduct study using secondary data from Indonesian Demographic and Health Survey (IDHS) in 2017. The IDHS was part of the international Demographic and Health Survey (DHS) program conducted by the Inner City Fund (ICF). The IDHS was a crossectional survey. The study population was women aged 15-49 years old who had given birth in the last five years in Eastern Indonesia. The study covered all provinces in Eastern Indonesia, namely East Nusa Tenggara, Maluku, North Maluku, West Papua, and Papua [19]. The study takes samples through stratification and multistage random sampling methods. By the procedure, the study employs a weighted sample size of 2299 respondents.

\section{Outcome variable}

The study defines hospital-based birth delivery as a delivery carried out in hospitals, government, and private hospitals. Hospital-based birth consists of two categories: no and yes.

\section{Exposure variables}

Health insurance ownership was the respondent's recognition of owned insurance, whether run by the government or the private sector. Health insurance ownership consists of two categories, namely uninsured and insured.

\section{Control variables}

Apart from health insurance ownership, other variables analyzed as control variables were province, residence type, age group, marital status, education level, employment status, parity, and wealth status. The study selected control variables based on previous studies on the same theme [20-22].

The provinces consist of East Nusa Tenggara, Maluku, North Maluku, West Papua, and Papua. Meanwhile, the residence type consists of two categories, namely urban and rural. This categorization refers to Statistics Indonesia. The age group consists of seven classes in 5 years, namely $15-19,20-24,25-29,30-34,35-39,40-$ 44, and 45-49. Marital status consists of three categories: never in a union, married/living with a partner, and widowed/divorced. Education level was the respondent's recognition of the last diploma they have. Meanwhile, education level consists of four categories: no education, primary, secondary, and higher. Parity was the number 
of living children that have been born. Parity consists of three types, namely primiparous $(\leq 1)$, multiparous [24], and grand multiparous $(>4)$ [23].

The IDHS calculated wealth status based on the wealth quintile owned by a household. Households were scored based on the numbers and types of items they had, from televisions to bicycles or cars, and housing characteristics, such as drinking water sources, toilet facilities, and primary building materials for the house's floor. The IDHS calculated the score using principal component analysis. National wealth quintiles were arranged based on household scores for each person in the household and divided by the distribution into the same five categories, accounting for $20 \%$ of the population. Wealth status consists of five classes: the poorest, poorer, middle, richer, and the richest [24].

\section{Statistical analysis}

The initial stage analysis used chi-square to analyze the disparity characteristics of health insurance ownership and other variables. In the final stage, because of the dependent variable's nature, binary logistic regression was used to determine health insurance ownership disparities and determine the adjusted odds ratio (AOR) with a 95\% confidence interval (CI). The binary logistic regression used "hospital delivery $=$ no" as references. The authors carry out all stages of statistical analysis using SPSS 21.

\section{Ethical approval}

The 2017 IDHS has obtained ethical clearance from the National Ethics Committee in Indonesia. The authors deleted all the respondents' identities from the dataset. Respondents have provided written approval for their involvement in the study. The researcher has obtained permission to use the 2017 IDHS data through the website: https://dhsprogram.com for this study.

\section{Results}

The analysis results found that, on average, women in Eastern Indonesia in 2017 made hospital deliveries of $28.5 \%$. Meanwhile, the average health insurance ownership in Eastern Indonesia in 2017 was 61.5\%.

\section{Descriptive analysis}

Table 1 displays descriptive statistics of health insurance ownership of respondents in Eastern Indonesia. Based on a hospital delivery, it shows that uninsured women rule both categories of hospital delivery. Based on the province, uninsured women occupy all regions. Meanwhile, based on the type of place of residence, uninsured women also dominate in both areas, with a more significant proportion of uninsured in rural areas.
According to the age group, uninsured women led in all age groups categories. Based on marital status, uninsured women ruled all types. Moreover, uninsured women occupied all classes based on education level, except for the higher education group, which insured women dominated.

Table 1 shows that the uninsured women prevalence in all employment status categories. Meanwhile, based on parity, uninsured women rule in all parity types. Finally, based on wealth status, the uninsured women ruled in the poorest and poorer categories; on the other hand, the insured women led in the middle, richer, and the richest categories.

\section{Multivariable analysis}

Table 2 shows that insured women are 1.426 times more likely than uninsured women to have hospital delivery (AOR 1.426; 95\% CI 1.426-1.427). This analysis indicates that having health insurance will be more likely to have birth delivery in the hospital in eastern Indonesia for hospital delivery. There is still a disparity between insured and uninsured women in hospital-based birth deliveries in the east of Indonesia. Insured women are nearly one and a half times more likely than uninsured women to give birth in a hospital.

The adjusted odds ratios for the health insurance ownership variable are smaller than the unadjusted odds ratios. The value of unadjusted odds ratios is 2.013 (OR 2.013; 95\% CI 1.652-2.453).

Apart from health insurance ownership, all other independent variables analyzed were significant determinants of hospital delivery in Eastern Indonesia. According to the province, women in Maluku and North Maluku are less likely than women in East Nusa Tenggara to carry out hospital delivery. Meanwhile, West Papua and Papua women have a higher probability than women in East Nusa Tenggara for hospital delivery.

Based on the age group, women in 20-24, 25-29, and 30-34 age groups were less likely than women in the 15-19 age group to have hospital delivery. Meanwhile, women in the 35-39, 40-44, and 45-49 age groups had a higher chance than women in the 15-19 age group to have hospital delivery.

Married/living with partner women were 1.342 times more likely than never in union women to undertake hospital delivery (AOR 1.342; 95\% CI 1.340-1.344). Moreover, widowed/divorced women were 0.690 times less likely than never in union women to do hospital delivery (AOR 0.690; 95\% CI 0.688-0.691).

Women with primary education are 3.379 times more likely than no educated women to have hospital delivery (AOR 3.379; 95\% CI 3.375-3.383). Women with secondary education have a 5.175 times chance of education for hospital delivery (AOR 5.175; 95\% CI 5.169-5.182). 
Table 1 Descriptive statistics of health insurance ownership of respondents in Eastern Indonesia in $2017(n=2299)$

\begin{tabular}{|c|c|c|c|c|c|}
\hline \multirow[t]{3}{*}{ Variables } & \multicolumn{5}{|c|}{ Health Insurance Ownership } \\
\hline & \multicolumn{2}{|c|}{ Uninsured } & \multicolumn{2}{|c|}{ Insured } & \multirow{2}{*}{$\begin{array}{l}p- \\
\text { value }\end{array}$} \\
\hline & $\mathrm{n}$ & $\%$ & $\mathrm{n}$ & $\%$ & \\
\hline Hospital delivery & & & & & $<0.001$ \\
\hline No & 707 & $79.8 \%$ & 179 & $20.2 \%$ & \\
\hline Yes & 936 & $66.2 \%$ & 477 & $33.8 \%$ & \\
\hline Province & & & & & $<0.001$ \\
\hline East Nusa Tenggara & 601 & $71.6 \%$ & 238 & $28.4 \%$ & \\
\hline Maluku & 480 & $72.9 \%$ & 178 & $27.1 \%$ & \\
\hline North Maluku & 292 & $79.1 \%$ & 77 & $20.9 \%$ & \\
\hline West Papua & 111 & $57.5 \%$ & 82 & $42.5 \%$ & \\
\hline Papua & 159 & $66.3 \%$ & 81 & $33.8 \%$ & \\
\hline Type of place of residence & & & & & $<0.001$ \\
\hline Urban & 332 & $51.6 \%$ & 312 & $48.4 \%$ & \\
\hline Rural & 1311 & $79.2 \%$ & 344 & $20.8 \%$ & \\
\hline Age group & & & & & $<0.001$ \\
\hline $15-19$ & 62 & $71.3 \%$ & 25 & $28.7 \%$ & \\
\hline $20-24$ & 285 & $77.9 \%$ & 81 & $22.1 \%$ & \\
\hline $25-29$ & 409 & $74.2 \%$ & 142 & $25.8 \%$ & \\
\hline $30-34$ & 418 & $71.3 \%$ & 168 & $28.7 \%$ & \\
\hline $35-39$ & 296 & $67.1 \%$ & 145 & $32.9 \%$ & \\
\hline $40-44$ & 128 & $62.4 \%$ & 77 & $37.6 \%$ & \\
\hline $45-49$ & 45 & $71.4 \%$ & 18 & $28.6 \%$ & \\
\hline Marital status & & & & & $<0.001$ \\
\hline Never in union & 20 & $74.1 \%$ & 7 & $25.9 \%$ & \\
\hline Married/Living with partner & 1553 & $71.2 \%$ & 629 & $28.8 \%$ & \\
\hline Widowed/Divorced & 70 & $77.8 \%$ & 20 & $22.2 \%$ & \\
\hline Education Level & & & & & $<0.001$ \\
\hline No education & 72 & $87.8 \%$ & 10 & $12.2 \%$ & \\
\hline Primary & 526 & $82.4 \%$ & 112 & $17.6 \%$ & \\
\hline Secondary & 836 & $72.3 \%$ & 320 & $27.7 \%$ & \\
\hline Higher & 209 & $49.4 \%$ & 214 & $50.6 \%$ & \\
\hline Employment status & & & & & $<0.001$ \\
\hline Unemployed & 816 & $73.0 \%$ & 302 & $27.0 \%$ & \\
\hline Employed & 827 & $70.0 \%$ & 354 & $30.0 \%$ & \\
\hline Parity & & & & & $<0.001$ \\
\hline Primiparous & 391 & $64.1 \%$ & 219 & $35.9 \%$ & \\
\hline Multiparous & 943 & $73.3 \%$ & 343 & $26.7 \%$ & \\
\hline Grandmultiparous & 309 & $76.7 \%$ & 94 & $23.3 \%$ & \\
\hline Wealth status & & & & & $<0.001$ \\
\hline Poorest & 1204 & $81.9 \%$ & 266 & $18.1 \%$ & \\
\hline Poorer & 237 & $62.7 \%$ & 141 & $37.3 \%$ & \\
\hline Middle & 95 & $47.0 \%$ & 107 & $53.0 \%$ & \\
\hline Richer & 80 & $48.8 \%$ & 84 & $51.2 \%$ & \\
\hline Richest & 27 & $31.8 \%$ & 58 & $68.2 \%$ & \\
\hline
\end{tabular}


Table 2 The results of binary logistic regression of hospital delivery in Eastern Indonesia in 2017 ( $n=2299)$

\begin{tabular}{|c|c|c|c|c|}
\hline \multirow[t]{3}{*}{ Variables } & \multicolumn{4}{|c|}{ Hospital Delivery } \\
\hline & \multirow{2}{*}{$\begin{array}{l}p- \\
\text { value }\end{array}$} & \multirow[t]{2}{*}{ AOR } & \multicolumn{2}{|l|}{$95 \% \mathrm{Cl}$} \\
\hline & & & Lower Bound & Upper Bound \\
\hline Health insurance: No & - & - & - & - \\
\hline Health insurance: Yes & $<0.001$ & 1.426 & 1.426 & 1.427 \\
\hline Province: East Nusa Tenggara & - & - & - & - \\
\hline Province: Maluku & $<0.001$ & 0.477 & 0.476 & 0.477 \\
\hline Province: North Maluku & $<0.001$ & 0.443 & 0.443 & 0.443 \\
\hline Province: West Papua & $<0.001$ & 1.068 & 1.067 & 1.068 \\
\hline Province: Papua & $<0.001$ & 1.208 & 1.207 & 1.208 \\
\hline Type of place: Urban & - & - & - & - \\
\hline Type of place: Rural & $<0.001$ & 0.376 & 0.375 & 0.376 \\
\hline Age group: 15-19 & - & - & - & - \\
\hline Age group: 20-24 & $<0.001$ & 0.581 & 0.580 & 0.581 \\
\hline Age group: 25-29 & $<0.001$ & 0.640 & 0.640 & 0.641 \\
\hline Age group: 30-34 & $<0.001$ & 0.934 & 0.933 & 0.935 \\
\hline Age group: $35-39$ & $<0.001$ & 1.404 & 1.403 & 1.406 \\
\hline Age group: $40-44$ & $<0.001$ & 2.555 & 2.552 & 2.558 \\
\hline Age group: $45-49$ & $<0.001$ & 2.356 & 2.352 & 2.359 \\
\hline Marital: Never in union & - & - & - & - \\
\hline Marital: Married/Living with partner & $<0.001$ & 1.342 & 1.340 & 1.344 \\
\hline Marital: Widowed/Divorced & $<0.001$ & 0.690 & 0.688 & 0.691 \\
\hline Education: No education & - & - & - & - \\
\hline Education: Primary & $<0.001$ & 3.379 & 3.375 & 3.383 \\
\hline Education: Secondary & $<0.001$ & 5.175 & 5.169 & 5.182 \\
\hline Education: Higher & $<0.001$ & 10.225 & 10.212 & 10.238 \\
\hline Employment: Unemployed & - & - & - & - \\
\hline Employment: Employed & $<0.001$ & 0.954 & 0.954 & 0.955 \\
\hline Parity: Primiparous & - & - & - & - \\
\hline Parity: Multiparous & $<0.001$ & 0.610 & 0.610 & 0.610 \\
\hline Parity: Grandmultiparous & $<0.001$ & 0.462 & 0.462 & 0.462 \\
\hline Wealth: Poorest & - & - & - & - \\
\hline Wealth: Poorer & $<0.001$ & 1.642 & 1.641 & 1.642 \\
\hline Wealth: Middle & $<0.001$ & 2.208 & 2.207 & 2.210 \\
\hline Wealth: Richer & $<0.001$ & 1.944 & 1.942 & 1.945 \\
\hline Wealth: Richest & $<0.001$ & 1.626 & 1.624 & 1.627 \\
\hline
\end{tabular}

Note: $95 \% \mathrm{Cl} ; A O R$ adjusted odds ratio

Finally, women with higher education are 10.225 times more likely than no education women to undertake hospital delivery (AOR 10.225; 95\% CI 10.212-10.238). This analysis shows that the better the education level, the more likely it is for women in Eastern Indonesia to make hospital delivery.

Employed women were 0.954 times less likely than unemployed women for hospital delivery (AOR 0.954; 95\% CI 0.954-0,955). This information shows that unemployment is a protective factor for women in Eastern Indonesia to do hospital delivery.

According to parity, multiparous women are 0.610 times more likely than women who do not have children or have one child to undertake hospital delivery (AOR 0.610; 95\% CI 0.610-0.610). Meanwhile, grand multiparous women were 0.462 times less likely than women who do not have children or have one child to undertake hospital delivery (AOR 0.462; 95\% CI 0.462-0.462). 
These multivariate test results inform that the more children who have been born, the less likely it is for women in Eastern Indonesia to have hospital delivery.

Table 2 informs that according to wealth status, women in a more deficient category were 1.642 times more likely than the poorest women to do hospital delivery (AOR 1.642; 95\% CI 1.641-1.642). Women in the middle category were 2.208 times more likely than the poorest women for hospital delivery (AOR 2.208; 95\% CI $2.207-2.210$ ). The richer category women were 1.944 times more likely than the poorest women to do hospital delivery (AOR 1.944; 95\% CI 1.942-1.945). Finally, women in the wealthiest category are 1.626 times more likely than the poorest women to do hospital delivery (AOR 1.626; 95\% CI 1.624-1.627). This information shows that all wealth status categories have a higher probability of making hospital delivery than the poorest.

\section{Discussion}

The analysis found that having health insurance will be more likely to have birth delivery in the hospital in Eastern Indonesia to carry out hospital delivery. This analysis results in line with the objectives of Indonesia's health financing policies that seek to realize National Health Insurance (NHI) with total coverage to minimize the barrier to health financing in Indonesia $[15,25]$. This study's results align with several previous studies on health insurance in various countries [26-28].

The results of this study provide a clear policy direction. The Indonesian government can push for policies that focus on increasing public participation in National Health Insurance to increase childbirth in eastern Indonesia. The Indonesian government can also optimize local governments' role, for example, by conducting cost-sharing assistance for National Health Insurance contributions for poor people [25].

For eastern Indonesia, having health insurance is not enough because it will only cover service costs. Meanwhile, east Indonesia has extreme geographical characteristics, including archipelagic topography, making transportation costs expensive $[10,11,29]$. These characteristics often make health development in this region lag behind other Indonesian areas [30, 31]. Other policy interventions are still needed to complement the $\mathrm{Na}$ tional Health Insurance policy.

In addition to health insurance ownership as exposure, this study also finds control variables as factors that also affect hospital delivery in eastern Indonesia. The study results inform that there are still disparities in hospital utilization between regions (provinces) for delivery. The information on this study's results is consistent with previous studies that inform that this disparity starts from an unbalanced input of health resources [32, 33]. On the other hand, the Papua Health Insurance, initiated by the local governments in West Papua and Papua, has proven to encourage hospital delivery [10]. West Papua and Papua Provinces have better utilization of hospital delivery services than other provinces in Eastern Indonesia.

The research analysis found that the age group is one of the determinants of women in Eastern Indonesia for hospital delivery. The older a woman is, the higher the chances of having her delivered to the hospital. Perhaps this is related to self-confidence because of previous experience or because pregnant women are increasingly aware of pregnancy and childbirth as they age [34]. Other authors also found age as a factor related to hospital delivery. The authors conduct the study in 34 countries in sub-Saharan Africa [35].

The multivariate analysis results found that having a partner (married/living with a partner) will be more likely for women in Eastern Indonesia to undertake hospital delivery. Psychologically, having a partner makes a woman have a place to share the burden, including the burden of financing related to childbirth costs [36]. Moreover, several previous studies have also found husbands' involvement has increased health services utilization [37, 38]. In the Indonesian context, this condition follows local values and local culture, which views a pregnant woman without a partner as a disgrace [39, 40], so pregnant women without a partner tend to hide their pregnancy and childbirth.

The study found education will be more likely to give birth for women in Eastern Indonesia to undertake hospital delivery. The better the level of education, the higher the possibility of women in Eastern Indonesia launching hospital delivery. The higher the woman's education, the more independent she is in determining what is best [41]. This finding is in line with the results of previous studies in Bangladesh and Ethiopia [42, 43]. Generally, several lessons that inform better education levels are a strong determinant of better health output $[19,44,45]$. Otherwise, poor education is known as a barrier to achieving better health output $[16,46]$.

The study found unemployed will be more likely to have a birth for women in Eastern Indonesia to conduct hospital delivery. It is possible that this situation can occur because unemployed women have a better time to prepare for delivery, including better choices of places for delivery. This study's results align with previous studies in Indonesia that analyzed IDHS data in 2013 [47].

According to parity, the results found that the more children who have been born, the less likely women in Eastern Indonesia are to have hospital delivery. Women in Eastern Indonesia with higher parity are likely to be more confident about delivering at a facility other than a hospital. Previous birth experiences also influence the choice of place of delivery [35]. an earlier study in Southern Ethiopia also confirmed similar findings [43]. 
According to wealth status, the study found that all wealth status categories have a higher probability than the poorest to make hospital delivery. In other words, poverty is a barrier for women in Eastern Indonesia to undertake hospital delivery. This situation is what the government wants to overcome, removing the public's financing barrier to access health services by releasing the NHI policy [25]. Several previous studies confirmed wealth status as a strong predictor of better health performance $[24,48-50]$.

\section{Study limitation}

This study carries out limitations as a consequence of the use of secondary data received. Studies analyze superficial data. The study does not consider cultural factors and beliefs known in previous studies to influence women's choice to deliver in the hospital or not [51-53]. On the other hand, the 2017 IDHS is a crosssectional survey, and hence the findings drawn are not causal.

\section{Conclusions}

The authors concluded that health insurance ownership disparities for hospital deliveries in Eastern Indonesia were based on the study results. Insured women have a better chance than uninsured women for hospital delivery.

The implication of this study's results is related to the health financing policy carried out by the Indonesian government through a social insurance mechanism called National Health Insurance. If the government wants to encourage deliveries to hospitals, the government must formulate policies to increase Eastern Indonesia's community participation in National Health Insurance.

\section{Acknowledgments}

The author would like to thank ICF International for agreeing to allow this paper to review the 2017 IDHS data.

\section{Authors' contributions}

ADL developed the proposal, analyzed and interpreted the patient data. RDW was a significant contributor in conducting the study, interpreting the data, and writing the manuscript. ZZ and NN were substantial contributors to research, analyzing the data, and writing the manuscript. All authors read and approved the final manuscript.

\section{Funding}

Not applicable.

\section{Availability of data and materials}

The authors cannot share data because a third party and authors who own the data do not have permission to share it. The 2017 IDHS data set name requested from the ICF ('data set of childbearing age women') are available from the ICF contact via https://www.dhsprogram.com for researchers who meet the criteria for access to confidential data.

\section{Declarations}

Ethics approval and consent to participate

The 2017 IDHS has passed ethical clearance from the National Ethics Committee. The research deletes respondents' identities from the dataset. Respondents have provided written approval for their involvement in the study. The author has obtained permission for the use of data for this study through the website: https://dhsprogram.com.

\section{Consent for publication}

Not applicable.

\section{Competing interests}

The authors declare that they have no competing interests.

\section{Author details}

${ }^{1}$ National Institute of Health Research and Development, the Ministry of Health of the Republic of Indonesia, Jakarta, Indonesia. ${ }^{2}$ Persakmi Institute, Surabaya, Indonesia. ${ }^{3}$ Faculty of Public Health, Universitas Airlangga, Surabaya, Indonesia. ${ }^{4}$ Faculty of Psychology and Health, UIN Sunan Ampel, Surabaya, Indonesia. ${ }^{5}$ STIKes Tengku Maharatu Tengku Maharatu, Pekanbaru, Indonesia.

Received: 1 February 2021 Accepted: 28 October 2021

Published online: 22 November 2021

References

1. World Health Organization. Maternal mortality : level and trends 2000 to 2017. Sex Reprod Health. 2019:12.

2. Barredo L, Agyepong I, Liu G, Reddy S. Ensure healthy lives and promote well-being for all at all ages. UN Chron. 2015;51(4):9-10. https://doi.org/10.1 8356/3bfe3cfa-en.

3. Ministry of Health of The Republic of Indonesia. Indonesia Health Data and Information: The Indonesia Health Profile. 8, Profil Kesehatan Indonesia. Jakarta; 2020. Availiable from https://www.kemkes.go.id/downloads/ resources/download/pusdatin/profil-kesehatanindonesia/Profil-KesehatanIndonesia-Tahun-2020.pdf

4. WHO, UNICEF, UNFPA WBG and, Division the UNP. Trends in Maternal Mortality 2000-2017. World Health Organization Geneva; 2019. Available from: www.who.int/reproductivehealth/publications/maternal-mortality-201 7/en/

5. Mbachu II, Ezeama C, Osuagwu K, Umeononihu OS, Obiannika C, Ezeama N. A cross sectional study of maternal near miss and mortality at a rural tertiary centre in southern nigeria. BMC Pregnancy Childbirth. 2017;17(1): 251.

6. Afifah T, Tejayanti T, Saptarini I, Rizkianti A, Usman Y, Senewe FP, et al. Maternal death in Indonesia: follow-up study of the 2010 Indonesia population census. Indones J Reprod Heal. 2016;7(1):1-13. https://doi.org/1 0.22435/kespro.v7i1.5102.1-13.

7. Say L, Chou D, Gemmill A, Tunçalp Ö, Moller ABA-BB, Daniels J, et al. Global causes of maternal death: a WHO systematic analysis. Lancet Glob Health. 2015;2(6):e323-33. https://doi.org/10.1016/S2214-109X(14)70227-X.

8. Masturoh M, Pamuji SE, Siswati S. Path analysis: three late causes of maternal death in Brebes district (path analisis: tiga keterlambatan penyebab kematian maternal di kabupaten brebes). Pena Med. 2018;8(1):18.

9. Pardosi J, Parr N, Muhidin S. Local Government and Community Leaders' perspectives on Child Health and Mortality and Inequity Issues in Rural Eastern Indonesia. J Biosoc Sci. 2017:49(1):123.

10. Laksono AD, Wulandari RD. Predictors of hospital utilization among Papuans in Indonesia. Indian J Forensic Med Toxicol. 2020;14(2):2319-24.

11. Laksono AD, Wulandari RD, Soedirham O. Regional Disparities of Health Center Utilization in Rural Indonesia. Malaysian. J Public Health Med. 2019; 19(1):158-66

12. Mubasyiroh R, Nurhotimah E, Laksono AD. Health Service Accessibility Index in Indonesia (Indeks Aksesibilitas Pelayanan Kesehatan di Indonesia). In: Supriyanto S, Chalidyanto D, Wulandari RD, editors. Accessibility of health Services in Indonesia (Aksesibilitas Pelayanan Kesehatan di Indonesia). Jogjakarta: PT Kanisius; 2016. p. 21-58.

13. Mawarti Y, Utarini A, Hakimi M. Maternal care quality in near miss and maternal mortality in an academic public tertiary hospital in Yogyakarta, 
Indonesia: A retrospective cohort study. BMC Pregnancy Childbirth. 2017; 17(1):149.

14. Aizawa T. The impact of health insurance on out-of-pocket expenditure on delivery in Indonesia. Health Care Women Int. 2019;40(12):1374-95. https:// doi.org/10.1080/07399332.2019.1578778.

15. Wulandari RD, Laksono AD, Matahari R. The effects of health insurance on maternity Care in Health Services in Indonesia. Int J Innov Creat Chang. 2020;14(2):478-97.

16. Laksono AD, Wulandari RD. The Barrier to Maternity Care in Rural Indonesia. J Public Heal From Theory to Pract. 2020; Online First. https://doi.org/10.1 007/s10389-020-01274-3

17. Sari B, Idris H. Determinant of independent national health insurance ownership in Indonesia. Malays J Public Heal Med. 2019;19(2):109-15. https://doi.org/10.37268/mjphm/vol.19/no.2/art.177.

18. Nasution SK, Mahendradhata Y, Trisnantoro L. Can a National Health Insurance Policy Increase Equity in the utilization of skilled birth attendants in Indonesia? A secondary analysis of the 2012 to 2016 National SocioEconomic Survey of Indonesia. Asia Pac J Public Health. 2020;32(1):19-26. https://doi.org/10.1177/1010539519892394.

19. Ipa M, Widawati M, Laksono AD, Kusrini I, Dhewantara PW. Variation of preventive practices and its association with malaria infection in eastern Indonesia: findings from community-based survey. PLoS One. 2020;15(5): e0232909. https://doi.org/10.1371/journal.pone.0232909.

20. Laksono AD, Wulandari RD, Rukmini R. The determinant of healthcare childbirth among young people in Indonesia. J Public Health Res. 2021; 10(1):28-34. https://doi.org/10.4081/jphr.2021.1890

21. Efendi F, Aidah FN, Has EMM, Lindayani L, Reisenhofer S, Ni'Mah AR, et al. Determinants of facility-based childbirth in Indonesia. Sci World J. 2019: 9694602.

22. Adde KS, Dickson KS, Amu H. Prevalence and determinants of the place of delivery among reproductive age women in sub-Saharan Africa. PLoS One. 2020;15(12 December):1-14.

23. Wulandari RD, Laksono AD. Is parity a predictor of neonatal death in Indonesia? Analysis of the 2017 Indonesia demographic and health survey. Indian J Forensic Med Toxicol. 2020;14(3):2161-6.

24. Wulandari RD, Qomarrudin MB, Supriyanto S, Laksono AD. Socioeconomic disparities in hospital utilization among elderly people in Indonesia. Indian J Public Health Res Dev. 2019:10(11):1800-4.

25. Anindya K, Lee JT, McPake B, Wilopo SA, Millett C, Carvalho N. Impact of Indonesia's national health insurance scheme on inequality in access to maternal health services: a propensity score matched analysis. J Glob Health. 2020;10(1):1-12. https://doi.org/10.7189/jogh.10.010429.

26. Zhang F, Shi X, Zhou Y. The impact of health insurance on healthcare utilization by migrant workers in China. Int J Environ Res Public Health. 2020;17(6):1852

27. Sisira Kumara A, Samaratunge R. Health insurance ownership and its impact on healthcare utilization: evidence from an emerging market economy with a free healthcare policy. Int J Soc Econ. 2019;47(2):244-67. https://doi.org/1 0.1108/IJSE-05-2019-0333.

28. Miraldo M, Propper C, Williams RI. The impact of publicly subsidised health insurance on access, behavioural risk factors and disease management. Soc Sci Med. 2018;217:135-51. https://doi.org/10.1016/j.socscimed.2018.09.028.

29. Laksono AD, Rukmini R, Wulandari RD. Regional disparities in antenatal care utilization in Indonesia. PLoS One. 2020;15(2):e0224006. https://doi.org/10.13 71/journal.pone.0224006

30. Ipa M, Laksono ADAD, Astuti EPEP, Prasetyowati H, Hakim L. Predictors of malaria incidence in rural eastern Indonesia. Indian J Forensic Med Toxicol. 2020;14(4):2994-3000.

31. Suparmi, Kusumawardani N, Nambiar D, Trihono, Hosseinpoor AR. Subnational regional inequality in the public health development index in Indonesia. Glob Health Action. 2018;11(1):41-53.

32. Pratiwi NL, Suprapto A, Laksono AD, Rooshermiati B, Rukmini PG, et al. Policy review on the distribution of health operational assistance funds in support of achieving maternal and child health (MDG's 4,5) in three districts, cities in East Java Province. Bul Penelit Sist Kesehat. 2014;17(4): 395-405.

33. Laksono AD, Ridlo IA. Ernawaty. Distribution Analysis of Doctors in Indonesia. 2019;2019 Available from: https://doi.org/10.31227/osf.io/df6ns.

34. Wulandari RD, Laksono AD. Determinants of knowledge of pregnancy danger signs in Indonesia. PLoS One. 2020;15(5):e0232550. https://doi.org/1 0.1371/journal.pone.0232550
35. Dunlop CL, Benova L, Campbell O. Effect of maternal age on facility-based delivery: Analysis of first-order births in 34 countries of sub-Saharan Africa using demographic and health survey data. BMJ Open. 2018;8(4):e020231.

36. Wai KM, Shibanuma A, Oo NN, Fillman TJ, Saw YM, Jimba M. Are husbands involving in their spouses' utilization of maternal care services?: A crosssectional study in Yangon, Myanmar. PLoS One. 2015;10(12):e0144135.

37. Maken ZHH, Nasir Idrees I, Zahid A, Zulfiqar A, Munib A, Hassan F, et al. Factors influencing father's antenatal and perinatal involvement in maternal health care. J Matern Neonatal Med. 2018;31(19):2569-75. https://doi.org/1 0.1080/14767058.2017.1347920.

38. Sakuma S, Yasuoka J, Phongluxa K, Jimba M. Determinants of continuum of care for maternal, newborn, and child health services in rural Khammouane, Lao PDR. PLoS One. 2019;14(4):e0215635.

39. Himawan KK. Singleness, sex, and spirituality: how religion affects the experience of being single in Indonesia. Ment Health Relig Cult. 2020;23(2): 1-12. https://doi.org/10.1080/13674676.2020.1767555.

40. Himawan KK, Bambling M, Edirippulige S. What Does It Mean to Be Single in Indonesia? Religiosity, Social Stigma, and Marital Status Among NeverMarried Indonesian Adults. SAGE Open. 2018;8(3).

41. Himawan KK, Bambling M, Edirippulige S. Modernization and singlehood in Indonesia: Psychological and social impacts. In: Kasetsart Journal of Social Sciences. Kasetsart University Research and Development Institute, vol. 40; 2019. p. 499-506.

42. Shahabuddin ASM, Delvaux T, Utz B, Bardaji A, De Brouwere V. Determinants and trends in health facility-based deliveries and caesarean sections among married adolescent girls in Bangladesh. BMJ Open. 2016; 6(9):e012424.

43. Asseffa NA, Bukola F, Ayodele A. Determinants of use of health facility for childbirth in rural Hadiya zone, Southern Ethiopia. BMC Pregnancy Childbirth. 2016;16(1):355.

44. Wulandari RD, Laksono AD. Education as predictor of the knowledge of pregnancy danger signs in rural Indonesia. Int J Innov Creat Chang. 2020; 13(1):1037-51.

45. Megatsari $H$, Laksono AD, Ibad M, Herwanto YT, Sarweni KP, Geno RAP, et al. The community psychosocial burden during the COVID-19 pandemic in Indonesia. Heliyon. 2020;6(10):e05136.

46. Rohmah N, Yusuf A, Hargono R, Laksono AD, Ibrahim I, et al. Determinants of teenage pregnancy in Indonesia. Indian J Forensic Med Toxicol. 2020; 14(3):2080-5.

47. Efendi F, Ni'Mah AR, Hadisuyatmana S, Kuswanto H, Lindayani L, Berliana SM. Determinants of facility-based childbirth in Indonesia. Sci World J. 2019; 2019:1-7. https://doi.org/10.1155/2019/9694602.

48. Ogundele OJ, Pavlova M, Groot W. Socioeconomic inequalities in reproductive health care services across Sub-Saharan Africa. A systematic review and meta-analysis. Sex Reprod Healthc. 2020;25(2020):100536.

49. Yaya S, Da F, Wang R, Tang S, Ghose B. Maternal healthcare insurance ownership and service utilisation in Ghana: analysis of Ghana demographic and health survey. PLoS One. 2019;14(4):1-13. https://doi.org/10.1371/journa I.pone.0214841.

50. Yuan Y, Louis C, Cabral H, Schneider JC, Ryan CM, Kazis LE Socioeconomic and Geographic Disparities in Accessing Nursing Homes With High Star Ratings. J Am Med Dir Assoc. 2018;19(10):852-9. https://doi.org/10.1016/j.ja mda.2018.05.017

51. Mulondo SA. Factors associated with underutilisation of antenatal care services in Limpopo. South Africa Br J Midwifery. 2020;28(11):788-95. https://doi.org/10.12968/bjom.2020.28.11.788.

52. Pratiwi NL, Fitrianti $Y$, Nuraini S, Rachmawati T, Laksono AD, Afreni M, et al. Concealed pregnant women or Kemel of Gayo ethnic in Blang Pegayon District, Gayo Lues District. Aceh Bull Heal Syst Res. 2019;22(2):81-90. https:/ doi.org/10.22435/hsr.v22i2.1693.

53. Laksono AD, Soerachman R, Angkasawati TJ. Case Study of Muyu Ethnic's Maternal Health in Mindiptara District-Boven Digoel (Studi Kasus Kesehatan Maternal Suku Muyu di Distrik Mindiptana, Kabupaten Boven Digoel). J Reprod Health. 2016;07/03:145-55.

\section{Publisher's Note}

Springer Nature remains neutral with regard to jurisdictional claims in published maps and institutional affiliations. 